\title{
Peningkatan Sikap Peduli Lingkungan Anak Prasekolah Melalui Bermain Peran “Aku Sayang Bumiku”
}

\author{
Nissa Tarnoto dan Wisjnu Martani \\ Fakultas Psikologi Universitas Ahmad Dahlan, Jln Kapas 9 Semaki Yogyakarta dan Fakultas Psikologi \\ Universitas Gadjah Mada nissa.tarnoto@psy.uad.ac.id dan wisjnu_m@ugm.ac.id
}

\begin{abstract}
Now global warming becomes the attention of all over the world. Global warming is probably caused by the increasing of the concentration of the greenhouse effects which is due to human activities. There are a lot of Indonesia people who do not care about their environment. Indonesia has to be aware of global warming such as the changing of the extreme weather, flood, clean water crisis, disease. Related to those problems, it needs to be appreciated the attitude of care for the environment since early. The objective of this research is to know whether the method of role playing is able to increase the attitude of care for the environment at the early stage of children. This research involved 29 preschool students. They were divided into 2 groups, control group and experiment group. The hypothesis was that there was the different attitude between two groups. The method which was used in this research was non - randomized pretest - posttest control only group design. From the statistical analysis using Paired Sample t-test showed that there was significantly difference for the experiment group before and after the conduct of role playing method “ I Love my Earth” ( $\mathrm{t}=11,168, \mathrm{p}=0,000)$. Statistical analysis using Independent sample $\mathrm{t}$ test with score gain $(\mathrm{t}=9,350, \mathrm{p}=0,000)$ showed that there was significantly different attitude of care for the environment between the experiment group and the control group $(t=9,350, p=$ $0,000)$.
\end{abstract}

Key word: The attitude of care for the environment, role playing, preschool

\begin{abstract}
ABSTRAK
Pemanasan Global menjadi perhatian masyarakat dunia saat ini. Pemanasan Global kemungkinan besar disebabkan oleh meningkatnya konsentrasi gas-gas rumah kaca akibat aktivitas manusia. Masyarakat Indonesia masih banyak yang tidak peduli dengan lingkungan. Indonesia bisa merasakan akibat pemanasan global seperti perubahan cuaca yang ekstrim, banjir, krisis air bersih, penyakit dimana-mana. Berkaitan dengan hal tersebut, perlu ditanamkan sikap peduli lingkungan sejak dini. Tujuan dari penelitian ini adalah untuk mengetahui apakah metode bermain peran dapat meningkatkan sikap peduli lingkungan pada anak usia dini. Subjek penelitian berjumlah 29 anak yang bersekolah di TK. Subjek dibagi menjadi kelompok kontrol dan kelompok eksperimen. Hipotesis yang diajukan adalah ada perbedaan perubahan peningkatan sikap peduli lingkungan anak usia dini (TK) antara kelompok eksperimen dengan kelompok kontrol. Metode yang digunakan dalam penelitian ini adalah non - randomized pretest - posttest control only group design. Hasil uji statistic Paired Sample t-test menunjukkan perbedaan yang sangat signifikan pada kelompok
\end{abstract}


eksperimen antara sebelum dan sesudah pemberian metode bermain peran "Aku Sayang Bumiku” $(\mathrm{t}=11,168, \mathrm{p}=0,000)$. Hasil uji statistik Independent sample $t$-test dengan gain skor $(\mathrm{t}=9,350$, $\mathrm{p}=0,000)$ menunjukkan adanya perbedaan sikap peduli lingkungan yang sangat signifikan antara kelompok eksperimen dengan kelompok $\operatorname{kontrol}(t=9,350, p=0,000)$.

Kata Kunci : Anak Usia Prasekolah. Bermain peran, Sikap Peduli Lingkungan,

\section{PENDAHULUAN}

Bumi tempat hidup manusia sudah tidak seperti dulu lagi. Bumi mengalami kerusakanyang diakibatkan aktivitas manusia, kini manusia diberbagai belahan dunia sepakat untuk menjaga kelestarian lingkungan hidup, bagaimanapun caranya. Global warming (pemanasan global) menjadi perhatian masyarakat dunia saat ini.

Peningkatan suhu rata-rata global sejak pertengahan abad ke-20 kemungkinan besar disebabkan oleh meningkatnya konsentrasi gasgas rumah kaca akibat aktivitas manusia. Aktivitas manusia yang dapat meningkatkan efek rumah kaca seperti pembakaran bahan bakar fosil, pembukaan hutan sehingga meningkatkan efek rumah kaca akibat meningkatnya CO2 (IPCC, 2007; Stott, Jones dan Mithchell, 2002).

Indonesia adalah negara dengan kekayaan alam melimpah, keanekaragaman flora dan fauna, dan hutan sebesar 62\% dari luas Indonesia sehingga Indonesia disebut juga paru-paru dunia. Berdasarkan laporan dari Badan Pusat Statistik (BPS) tahun 2010 Indonesia memiliki penduduk sejumalah 237,6 juta orang. Hal ini memungkinkan Indonesia juga menjadi penyumbang emisi baik secara langsung dan tidak langsung. Indonesia masuk dalam peringkat ke empat top dunia, yang menghasilkan emisi gas rumah kaca untuk tahun 2005 (MNP, 2007) sebanyak 6\% dari presentasi seluruh dunia.

Di Indonesia, efek pemanasan global sudah sangat terlihat seperti kenaikan intensitas dan frekuensi kejadian bencana alam (banjir, tsunami, gempa bumi), kenaikan air laut, kerusakan keanekaragaman hayati, penurunan sumber air bersih, musim kemarau yang lebih panjang, dll.(Dampak Perubahan iklim Indonesia masuk dalam kategori”sangat rentan”, 2007)

Pemanasan global tampaknya seperti masalah besar yang membuat manusia merasa tidak berdaya, tetapi sebenarnya ada banyak hal yang dapat manusia lakukan pada tingkat pribadi untuk membantu dan tidak memerlukan biaya banyak. Manusia hanya perlu mengubah sikap dan perilaku (Genevose,2007).

Bentuk-bentuk kesadaran dan kepedulian lingkungan sudah mulai tampak, ini terlihat dari kebijakan-kebijakan yang dikeluarkan oleh pemerintah maupun kegiatan yang dilakukan masyarakat. Program-program seperti gerakan sejuta pohon, peringatan hari bumi, maraknya kegiatan daur ulang kertas dan sampah, serta maraknya Lembaga Swadaya Masyarakat (LSM) yang memberi perhatian terhadap lingkungan hidup menunjukkan adanya peningkatan kepedulian lingkungan dikalangan masyarakat dan pemerintah Indonesia.

Disisi lain, masih banyak manusia yang tidak memiliki kepedulian dan kemauan untuk melestarikan lingkungan hidup. Berdasarkan data Badan Pusat Statistik tahun 2012 yang telah melakukan survey tentang Perilaku Peduli Lingkungan Hidup yang dilakukan di 33 Ibu Kota Provinsi dengan sampel sebanyak 3254. Indikator Perilaku Peduli Lingkungan Hidup antara lain komsumsi listrik, pengelolaan sampah, pemanfaatan air bersih, pengguanaan bahan bakar, emisi karbon, dan perilaku hidup sehat. Hasil survey menunjukkan bahwa dari berbagai 
indicator perilaku peduli lingkungan tersebut diperoleh skor hanya 0,57 dari rentang $1-10$, hal ini menunjukkan bahwa perilaku peduli lingkungan pada masyarakat Indonesia masih sangat rendah.

Banyak gerakan lingkungan yang dicanangkan dan merambah keseluruh lapisan masyarakat, industry, pemerintah tetapi belum mencapai pada lapisan di lingkungan pendidikan. Lingkunga pendidikan seharusnya menjadi fokus yang penting pada program lingkungan, karena dalam lingkungan pendidikan terdapat generasigenerasi penerus, sehingga perlu menanamkan perilaku peduli lingkungan di lingkungan sekolah dan sejak dini.

Berbagai hasil penelitian menyimpulkan bahwa perkembangan yang diperoleh pada saat usia dini sangat mempengaruhi perkembangan anak pada tahap berikutnya. Berkaitan dengan hal tersebut perlu ditumbuhkan kepedulian lingkungan sejak usia dini. Bagaimana cara menanamkan kepedulian lingkungan?. Inilah tugas masyarakat terutama masyarakat yang bergerak dalam dunia pendidikan, untuk mengkaji, mengembangkan dan bereksperimen tentang metode penerapannya dalam melaksanakan pembelajaran.

Usia dini merupakan usia yang sangat penting bagi perkembangan anak sehingga disebut golden age. Pada saat itu, perkembangan otak sebagai pusat kecerdasan terjadi sangat pesat. Perkembangan ini demikian pentingnya sehingga mendapat perhatian yang cukup luas dari para pakar psikologi atau pendidikan, yang menyatakan bahwa pendidikan untuk anak usia dini harus disesuaikan dengan pertumbuhan dan perkembangan anak. Prinsip tersebut dinamakan praktek-praktek yang sesuai dengan perkembangan anak (developmentally appropriate practice atau DAP) (Bredekamp, 1987).

Beberapa hal yang perlu diperhatikan dalam pelaksanaan kegiatan atau pembelajaran pada pendidikan anak usia dini (Bredekamp \&
Coople, 1997 dalam Aisah, 2008) : 1) mencakup semua aspek perkembangan anak (fisik, sosial, emosi, spiritual, dan kognitif) melalui pendekatan yang terpadu, 2) berorientasi pada perkembangan anak,(kegiatan dan materi pengembangan bersifat konkrit, nyata dan relevan dengan kehidupan anak, 3) berorientasi pada kebutuhan anak, 4) pembelajaran sebagai proses yang interaktif, 5) pengalaman, bahan, dan perlengkapan pengembangan, yang berbagai budaya (multikultur) dan tidak bias gender perlu dikembangkan untuk anak segala usia, 6) berbagai pengalaman dan kegiatan di luar ruang perlu diperkenalkan pada anak segala usia

Moeslichatoen (1999) menyebutkan bahwa ada tujuh metode pengajaran yang sesuai dengan karateristik anak usia Taman kanakkanak yaitu: bermain, karyawisata, bercakapcakap, bercerita, demonstrasi, proyek, dan pemberian tugas. Manfaat bermain bagi anak adalah memuaskan tuntutan dan kebutuhan perkembangan dimensi motorik, kognitif, kreativitas, bahasa, emosi, sosial, nilai dan sikap hidup.

Ciri khas yang sangat menonjol pada anak usia dini adalah bermain. Seluruh kegiatan bermain bagi anak pada awal pertumbuhannya merupakan aktivitas yang bertujuan untuk mengembangkan kapasitas otak anak. Oleh karenanya bermain dengan anak usia dini, dengan berbagai jenis mainan yang aman, menyenangkan penuh canda tawa, berarti sedang menumbuhkan dendrit atau sel syaraf otak yang akan mengembangkan triluyan sinapsis (Santrock, 2002). Salah satu perkembangan bermain anak usia pra sekolah (5-7 tahun) adalah anak cenderung menyukai permainan yang banyak melibatkan gerakan fisik secara aktif, dan ini bisa diperoleh dalam permainan bermain peran (Wulan,2011).

Kepedulian lingkungan menunjukkan sikap atau tindakan yang selalu berupaya mencegah kerusakan pada lingkungan alam di sekitarnya, dan mengembangkan upaya-upaya untuk 
memperbaiki kerusakan alam yang sudah terjadi (Kemendiknas, 2011). Hal ini dapat disamakan dengan istilah perilaku ramah lingkungan atau perilaku lingkungan yang bertanggung jawab. Perilaku bertanggung jawab terhadap lingkungan (Perilaku ramah lingkungan) adalah atribut komposit yang melibatkan kebiasaan pribadi dan tindakan kolektif. Perilaku yang dapat meminimalkan dampaknegatif pada lingkungan di kehidupan sehari-hari, seperti menulis pada kedua sisi kertas dan menempatkan kaleng dan botol plastik ke tempat sampah untuk didaur ulang. Tindakan kolektif lebih pada perilaku yang berorientasi mendorong orang lain untuk melakukan hal yang sama danmelakukan tekanan kolektif pada pemerintah agar bisa membentuk dan melaksanakan kebijakan publik yang berkaitan dengan lingkungan (Pui dan Yeung, 2002).

Sikap peduli lingkungan sebagai respon evaluative, baik berupa respon kognitif, afektif maupun konatif terhadap upaya mencegah kerusakan pada lingkungan alam di sekitarnya, dan mengembangkan upaya-upaya untuk memperbaiki kerusakan alam yang sudah terjadi.

Hines, et al, dalam Hwang, Kim dan Jeng, (2002) mengemukakan bahwa Perilaku peduli lingkungan terkait dengan faktor yang dapat dikategorikan kedalam :

1. Faktor Kognitif

Menurut Boerschig \& De Young, 1993: Hines et al. 1986 dalam Hwang, Kim dan Jeng, 2002 faktor kognitif terdiri dari pengetahuan tentang isu, pengetahuan tentang strategi tindakan, skill action.

2. Faktor afektif

Fokus pada feelings atau emosi yang diasosiasikan pada objek dan digeneralisis pada sikap, locus of control dan tanggung jawab. Locus of Control mengandung arti kepercayaan (beliefs) individu tentang kemampuan seseorang untuk membuat perubahan dalam lingkungannya dengan perilakunya (hines, et al., 1986: Hungerford
\& Volk, 1990).

\section{Faktor situasional}

Kendala ekonomi, tekanan sosial dan kesempatan untuk memilih tindakan yang berbeda, memperkuat atau melawan faktor afektif (Barr.2003).

Barr (2003) mengemukakan ada lima dimensi atau aspek dari perilaku tanggung jawab lingkungan yaitu penghematan energi, konservasi air, daur ulang dan manajemen sampah, transportasi berkelanjutan, dan pengurangan kebisingan. Berdasarkan pemaparan diatas dan pertimbangan subyek penelitian adalah anak usia dini, dalam penelitian ini aspek yang akan digunakan adalah: menghemat energy, konservasi air , manajemen sampah.

Bermain peran adalah metode pemecahan masalah dalam kelompok yang memungkinkan anak untuk menggali masalah manusia, direspon secara spontan dan diikuti diskusi terarah (Shaftel dan Shaftel 1982). Menurut Manorom dan Pallock (2006) bermain peran merupakan metode mengajar yang bermanfaat untuk mengembangkan ketrampilan maupun pengetahuan akademik melalui proses stimulasi lingkungan.

Dalam prakteknya, untuk pengembangan perilaku lingkungan yang bertanggung jawab (sikap peduli lingkungan) cara yang efektif adalah dengan menggunakan pendekatan pengajaran inquiry (Dewan Pengembangan Kurikulum, 1992; Stimpson, 1992, 1995; Yau, 1992). Pengajaran Enquiry dapat mengambil banyak bentuk, seperti penyelidikan umum (Boardman, 1988), simulasi, dan bermain peran dalam konteks studi kasus (Baku, 1989). Partisipasi dan aktif dikelas merupakan cara yang efektif untuk mengembangkan perilaku lingkungan yang bertanggung jawab (Zelezny, 1999).

Role play membuat anak memberlakukan situasi lebih dari sekedar membicarakan. Secara signifikan bermain peran memungkinkan anak lolos dari lingkungan kelas yang membosankan yang menuntut anak untuk berperilaku sesuai 
dengan aturan yang ada dikelas dan memungkinkan anak memiliki kebebasan memperoleh pengalaman (Laird dan House dalam Fanning, 2011; Wook dan Cook, 2009). Hal ini berkaitan dengan rentang konsentrasi anak usia dini yang hanya bisa berkonsentrasi skitar 5-10 menit (Berg dalam Aisah, 2008). Metode bermain peran ini juga pernah digunakan oleh Febriani tahun 2010 sebagai metode pengajaran untuk meningkatkan kecerdasan moral pada anak Pra sekolah, dan hasilnya menunjukkan bahwa kecerdasan moral anak prasekolah meningkat setelah diberikan melalui metode bermain peran.

Bermain peran juga dapat menumbuhkan delapan kecerdasan majemuk anak, salah satunya adalah kecerdasan naturalis. Kecerdasan naturalis menunjukkan kemampuan seseorang untuk peka dan cinta terhadap lingkungan alam (Departemen Pendidikan Nasional, 2006).

Berdasarkan paparan diatas, untuk menumbuhkan kepedulian lingkungan membutuhkan tiga aspek, yang melibatkan aspek pengetahuan, sikap (keinginan untuk bertindak dapat dipahami sebagai kesediaan untuk bertindak atas perilaku tertentu) dan perilaku. Hal ini didukung oleh Kraus dalam Myers (2008) dan Jackson (1995) bahwa sikap akan berpengaruh pada perilaku ketika seseorang selalu mengingatnya, mendapatkannya melalui pengalaman langsung dan ada koneksi antara apa yang kita pikirkan, rasakan dan apa yang kita lakukan. Penelitian ini bertujuan untuk mengetahui apakah metode bermain peran dapat meningkatkan sikap peduli lingkungan pada anak usia dini khususnya anak TK. Hipotesis penelitian ini adalah ada perubahan peningkatan sikap peduli lingkungan anak usia dini (TK) yang mendapatkan perlakuan bermain peran (kelompok eksperimen) dengan yang tidak mendapatkan perlakuan (kelompok kontrol). Subyek yang mendapat perlakuan bermain peran mempunyai sikap peduli lingkungan yang lebih tinggi dari pada yang tidak mendapat perlakuan metode bermain peran. Manfaat dari penelitian diharapkan bisa memberikan variasi metode dalam mengajarkan kepedulian lingkungan pada anak.

\section{METODE PENELITIAN}

Subyek penelitian ini adalah 29 siswa Taman kanak-kanak kelas B dari dua sekolah yang berbeda, yang akan dibagi menjadi kelompok kontrol dan kelompok eksperimen. Kriteri inklusi subyek adalah siswa Taman Kanak-Kanak yang memiliki usia 5-6 tahun baik laki-laki maupun perempuan dan memiliki sikap peduli lingkungan yang rendah. Sikap peduli lingkungan yang rendah diperoleh melalui pretest dengan skala peduli lingkungan

Instrumen dibuat dalam bentuk gambar dengan ukuran kertas $(21 \mathrm{~cm} \times 14,5 \mathrm{~cm})$. Instrumen berupa situasi dalam kehidupan (life setting) sehari-hari anak usia pra sekolah. Instrumen penelitian disusun oleh peneliti berdasarkan aspek-aspek: 1) Menghemat energy, 2) Konservasi air, 3) Manajemen sampah. Instrumen penelitian sikap peduli lingkungan terdiri dari sembilan gambar. Instrument alat ukur sebelumnya di uji validitas content menggunakan model validasi isi formula Aiken's V dengan koefisien validitas bergerak dari angka 0,5-1.0. Profesional Judgement untuk menilai content alat ukur yaitu dua Ahli dibidang psikologi anak/psikolog anak dan dua guru TK yang sudah berpengalaman mengajar selama \pm 15 tahun. Alat ukur kemudian diujicobakan kepada 30 subyek. Subyek adalah anak TK yang berasal dari sekolah yang berbeda dari kelompok control maupun eksperimen tapi masih dalam satu kota. Hasil uji coba menunjukkan koefisien reliabilitas sebesar 0,723 dan indeks daya beda yang diperoleh adalah antara 0,2680,704 .

Berikut contoh alat ukur yang digunakan dari indicator hemat penggunaan listrik. Siswa diminta untukmengidentifikasikan gambarterlebih 
dulu, hingga persepsi gambar sama dengan persepsi peneliti. Tahap kedua, kemudian asisten peneliti akan menanyakan kepada anak, apa yang akan dilakukan pada saat menghadapi situasi ( siang hari, tapi lampu masih dinyalakan) seperti pada gambar.

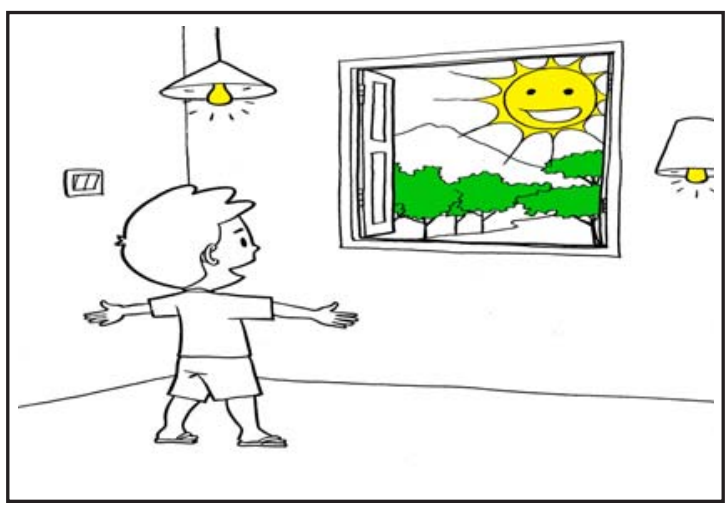

Gambar 1. Contoh alat ukur yang digunakan.

Jenis penelitian ini adalah eksperimen kuasi. Rancangan yang dipilih adalah untreated control group design with pretest-test and posttestt-test. Dalam penelitian ini, sikap peduli lingkungan pada anak TK akan dibandingkan sebelum dan sesudah pemberian metode bermain peran oleh guru. Hal ini dilakukan untuk melihat apakah metode bermain peran dapat meningkatkan sikap peduli lingkungan.

Tabel 1.Bagan Rancangan Eksperimen

\begin{tabular}{clcc}
\hline Kelompok & Pretest & Perlakuan & Posttest \\
\hline KE(NR) & O1 & X & O2 \\
KK(NR) & O1 & & O2 \\
\hline
\end{tabular}

Keterangan.

$\mathrm{KE}$ : Kelompok eksperimen,

KK : Kelompok control,

$\mathrm{X}$ : Metode Bermain Peran,

$\mathrm{O}_{1}$ : Pretest Kepedulian lingkungan,

$\mathrm{O}_{2}$ : Posttestkepedulian Lingkungan,

NR : Non Random
Perlakuan yang diberikan dalam penelitian ini adalah pengajaran dengan metode bermain peran.. Penyebab dari meningkatnya emisi gas rumah kaca terkandung dalam setiap situasi masalah. Tahapan dalam bermain peran disusun berdasarkan tahapan menurut Shaftel dan Shaftel (1982) dan modul yang disusun Febriani (2010) yang terdiri dari sembilan tahap yaitu: a)" Pemanasan” kelompok/Konfrontasi masalah (prolog), b)Pemilihan Partisipan (anak yang akan bermain peran/aktor), c) Menyiapkan penonton (anak atau siswa yang lain) untuk berpartisipasi sebagai pengamat (audience), d) Menyiapkan "panggung” (stage), e) Bermain Peran (role play), f) Membicarakan isi tema dan evaluasi, g) Bermain peran kembali (memainkan peran kembali yang sudah dibicarakan bersama dan dikoreksi, mengeksplorasi kemungkinan jalan keluar yang lain), h).Berbagi pengalaman dan generalisali. Total waktu yang dibutuhkan dalam mengaplikasikan modul bermain peran "Aku Sayang Bumiku” adalah \pm 45 menit.

Tahapan Penelitian:

1. Tahap Persiapan

Modul yang digunakan dalam penelitian ini disusun berdasarkan tahapan bermain peran yang dikemukakan oleh Shaftel \& Shaftel (1989) dan modul yang yang disusun oleh Febriani (2010). Penyusunan alat ukur sikap peduli lingkungan disusun berdasarkan aspek kepedulian lingkungan yang dikemukakan oleh Barr (2003).

2. Tahap Pelaksanaan

a. Penentuan Kelompok Penelitian

Kelompok penelitian adalah TK di daerah perkotaan. Berdasarkan angket yang disebarkan kepada 17 TK disatu gugus ditemukan bahwa ada dua TK yang belum menerapkan metode bermain peran dan belum mengajarkan tentang kepedulianlingkungan. DuaTK tersebut sama-sama memiliki standar 
kualitas yang sama yaitu sama-sama terakridatasi A. Penentuan kelompok kontrol dan kelompok eksperimen dengan cara diundi dengan gulungan kertas.. Sebelum mengikuti proses penelitian, orangtua subyek kelompok eksperimen diminta mengisi lembar persetujuan keterlibatan (informd consent) yang menyatakan subyek diijinkan terlibat dalam penelitian ini.

b. Sebelum diberikan metode bermain peran, peneliti meminta baik kelompok kontrol ataupun eksperimen untuk mengisi alat ukur penelitian (Pretest)

c. Pelaksanaan Metode bermain peran diberikan dengan enam kali pertemuan @+45 menit

d. Setelah selesai pemberian metode bermainperanolehguru, penelitimeminta baik kelompok eksperimen maupun kelompok kontrol untuk mengisi alat ukur kembali (Posttest), satu bulan kemudian penelitimelakukan follow-up

3. Tahap Analisis dan Pelaporan

Data yang diperoleh dari dua kelompok baik kelompok eksperimen maupun kelompok dianalisis. Analisis data dilakukan dengan menggunakan salah satu program dalam komputer yaitu SPSS (Statistical Package for Social Science) versi 15.0.

\section{HASIL DAN PEMBAHASAN}

Hasil analisis parametrik Independent Sample t- test dengan gain score. untuk mengetahui apakah ada perbedaan sikap peduli lingkungan antara kelompok eksperimen dan kelompok kontrol pada saat pretest-postestfollow up. Hasil analisis menunjukka t sebasar 9,350 ( $p<0,01$ ) hal ini menunjukkan ada perbedaan sikap peduli lingkungan yang sangat signifikan antara kelompok eksperimen dengan kelompok control, dimana ada peningkatan sikap peduli lingkungan pada kelompok eksperimen.

Tabel 2. Hasil Uji Gain Score Sikap Peduli lingkungan Pretest-Postest

\begin{tabular}{llcll}
\hline Kelompok & $\mathrm{N}$ & Mean & $\mathrm{t}$ & $\mathrm{S}$ ig \\
\hline Eksperimen & 15 & 9.67 & 9.350 & 0,000 \\
Kontrol & 14 & 1.00 & & \\
\hline
\end{tabular}

Analisis kedua menunjukkan t sebesar 5,376 ( $p<0.01)$. Hasil analisis data menunjukkan bahwa ada perbedaan sikap peduli lingkungan yang sangat signifikan antara kelompok eksperimen dengan kelompok kontrol setelah dilakukan follow up. Peneliti melakukan follow up dengan kembali menyajikan instrument alat ukur sikap peduli lingkungan kepada siswa pada kelompok kontrol dan kelompok eksperimen. Perubahan skor sikap peduli lingkungan dapat dilihat pada grafik berikut ini.

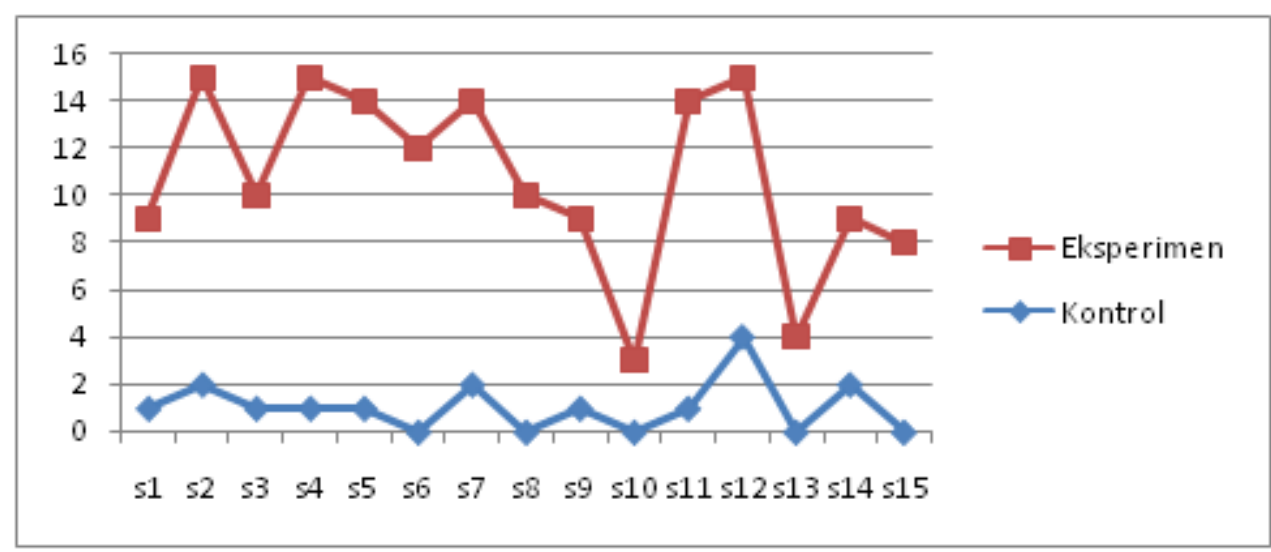

Gambar 2. Grafik Gain Score (Pretest-Postest) Kelompok Kontrol dan Kelompok Eksperimen 


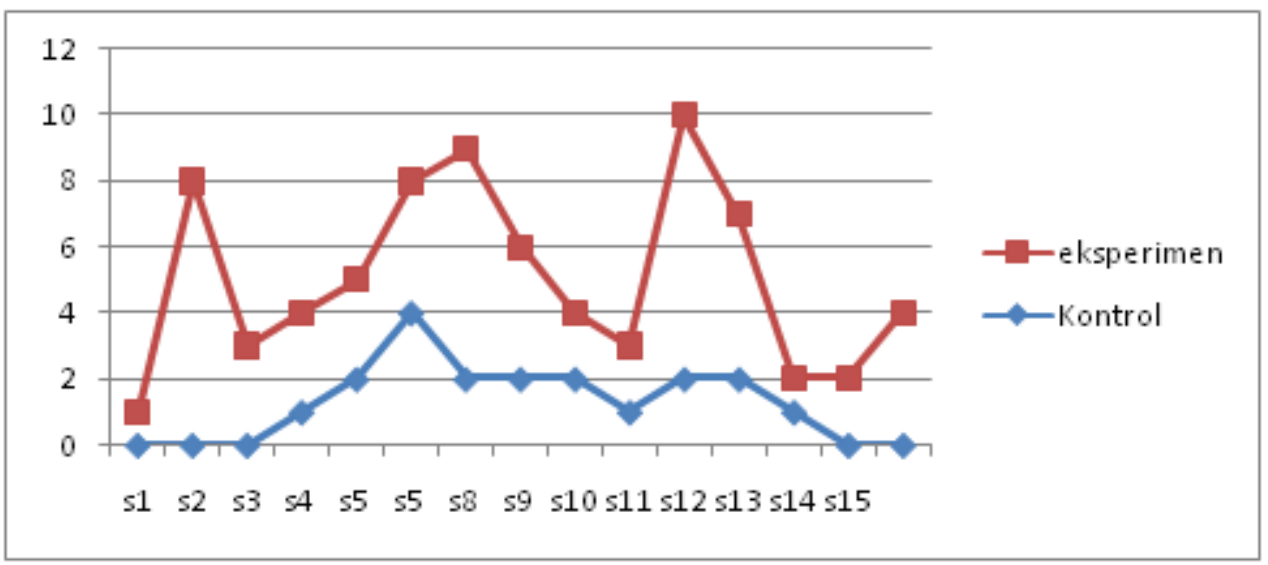

Gambar 3. Grafik Gain Score (Posttest-Followup) Kelompok kontrol dan Kelompok eksperimen

Menguji perbedaan antara skor sikap peduli lingkungan sebelum dan sesudah pelatihan pada kelompok eksperimen maupun kelompok kontrol menggunakan analisis statistik Paired Sample t-test._Hasil analisis data pada kelompok eksperimen sebelum dan sesudah pemberian motede bermain peran menunjukkan bahwa ada perbedaan yang sangat signifikan skor sikap peduli lingkungan pada kelompok eksperimen sebelum dan sesudah mendapatkan perlakuan pembelajaran dengan metode bermain peran. Hal ini ditunjukkan dengan nilai nilai $\mathrm{t}=11,168$, $(\mathrm{p}$ $<0.01)$.

Hasil analisis data pada kelompok kontrol sebelum dan sesudah pemberian motede bermain peran menunjukkan bahwa ada perbedaan yang signifikan skor pretest sikap peduli lingkungan dengan skor posttest sikap peduli lingkungan pada kelompok kontrol. Hal ini ditunjukkan dengan nilai nilai $\mathrm{t}=3.017, \mathrm{p}=$ $0,010(\mathrm{p}<0.05)$.

Penelitian ini bertujuan untuk mengetahui apakah metode bermain peran “ Aku Sayang Bumiku” dapat meningkatkan sikap peduli lingkungan pada anak usia dini khususnya anak TK. Berdasarkan analisis data, hipotesis penelitian ini terbukti yaitu ada perbedaan tingkat pencapaian sikap peduli lingkungan anak usia dini (TK) yang mendapatkan perlakuan bermain peran “Aku Sayang Bumiku” (kelompok eksperimen) dengan yang tidak mendapatkan perlakuan (kelompok kontrol) baik pada posttest maupun pada saat follow up. Tingkat pencapaian sikap peduli lingkungan subyek yang mendapatkan perlakuan metode bermain peran “Aku Sayang Bumiku” (kelompok eksperimen) lebih tinggi dibandingkan dengan subyek yang tidak mendapat perlakuan (kelompok kontrol). Hal ini mengindikasikan bahwa metode bermain peran “ Aku Sayang Bumiku” dapat menjadi salah satu alternatif metode untuk mengajarkan sikap peduli lingkungan pada anak usia dini khususnya TK.

Hal ini sesuai dengan teori yang mengemukakan bahwa, untuk mengembangkan sikap peduli lingkungan cara yang efektif adalah dengan menggunakan pendekatan pengajaran inquiry (Dewan Pengembangan Kurikulum, 1992; Stimpson, 1992, 1995; Yau, 1992). Salah satu bentuk pengajaran inquiry adalah bermain peran dalam konteks studi (Baku, 1989). Bermain peran juga dapat menumbuhkan delapan kecerdasan majemuk anak, salah satunya adalah kecerdasan naturalis. Kecerdasan naturalis menunjukkan kemampuan seseorang untuk peka dan cinta terhadap lingkungan alam (Departemen Pendidikan Nasional, 2006) . 
Bermain peran, membuat anak seolaholah dihadapkan pada kehidupan nyata, karena anak dituntut untuk merasakan (feel), berpikir (think), dan bertindak yaitu membuat keputusan dari berbagai sudut kemungkinan (Shaftel dan Shaftel, 1982). Anak mengalami proses berpikir pada saat membicarakan tema bersama dan berpendapat sesuai dengan apa yang dipikirkan dan pengalamannya. Pada saat membicarakan tema, akan belajar mendengarkan, memperhatikan dan bergantian mengemukakan pendapatnya. Setelah berpikir kembali dan mendengarkan pendapat teman yang lain, anak bisa merubah pilihan tindakannya dengan tindakan yang lebih cermat dan memerankannya di depan kelas. Proses berpikir, berpendapat dan memerankan dikelas inilah yang diharapkan dapat menstimulasi anak untuk memahami dan mampu menerapkan sikap peduli lingkungan.

Bermain peran adalah salah satu strategi pengajaran yang memberikan beberapa keuntungan bagi guru dan siswa. Pertama siswa akan lebih tertarik pada topik atau materi yang dibicarakan guru, dan meningkatkan minat subyek dalam pemahaman materi (Jarvis, Odell, dan Troiano, 2002; Riechert, Leander dan Lenhart, 2011).

Kedua bermain peran adalah salah satu metode pengajaran yang terpadu karena dengan bermain peran perkembangan anak seperti kognitif, motorik, bahasa, sosial, nilai dan sikap hidup dapat tersalurkan. Anak yang terlibat dalam bermain peran “Aku Sayang Bumiku” dapat memuaskan tuntunan perkembangan dimensi motorik (melalui kegiatan bermain peran), dimensi bahasa (belajar mengemukakan pendapat dikelas), dimensi sosial (anak berlatih untuk bergantian mengemukakan pendapat, dan memainkan peran), dimensi kognitif (pengetahuan tentang cara-cara mengurangi pemanasan global), dan sikap hidup (sikap peduli lingkungan). Hal ini juga dikemukakan oleh Bredekamp \& Coople dalam Asiah (2008) yang menyatakan bahwa untuk melaksanakan pembelajaran pada anak usia dini salah satu syaratnya adalah kegiatan tersebut harus mencakup semua aspek perkembangan seperti kognitif, motorik, bahasa, sosial, nilai dan sikap hidup sehingga mudah diterima oleh anak.

Bermain peran juga dinilai efektif jika dibandingkan dengan metode mengajar tradisional (guru adalah segalanya /Teacher Center Learning) dan suasana belajar yang terstruktur dan terkesan dipaksakan sehingga anak harus duduk diam. Bermain peran memungkinkan anak bersifat spontan, aktif tidak sekedar hanya membicarakan, tetapi juga bertindak (Shaftel \& Shaftel, 1982). Hal ini terkait bahwa anak akan lebih mudah menerima pengetahuan jika anak terlibat secara aktif dan memperoleh pengalaman langsung. Zelezny (1999) mengukapkan bahwa partisipasi dan aktif di kelas merupakan cara yang efektif untuk mengembangkan perilaku lingkungan yang bertanggung jawab atau sikap peduli lingkungan.

Pendapat ini juga didukung Moeslichatoen (1999), yaitu salah satu manfaat yang akan didapatkan anak dalam bermain adalah berkaitan dengan perkembangan kognitif. Vygotsky dalam Woolfook (2009) mengatakan bahwa perkembangan kognitif terjadi melalui percakapan dan interaksi anak dengan anggotaanggota yang lebih mampu di budayanya, orang dewasa atau teman sebaya yang lebih mampu yang berfungsi sebagai pemandu dan pengajar, memberikan informasi dan memberi dukungan yang dibutuhkan agar anak tumbuh secara intelektual. Selanjutnya faktor kognitif ini akan berpengaruh pada sikap, yang selanjutnya berakibat pada perilaku (Hungerford dan Volk,1990; Fisher \& Fisher, 1991 (dalam Oskamp, 2002); Newhouse, 1990; Barr, 2003; ). Goldman, Yavetz dan Pe'er (2006) mengemukakan bahwa pengetahuan lingkungan individu seseorang mencerminkan sikap seseorang terhadap lingkungan yang akan muncul dalam perilaku lingkungan. Harapannya adalah jika anak sudah mendapatkan pengetahuan 
tentang peduli lingkungan , maka anak tersebut juga bersikap dan berperilaku peduli terhadap lingkungan.

Hasil analisis tambahan yang dilakukan oleh peneliti menunjukkan bahwa ada peningkatan sikap peduli lingkungan pada saat posttest dikelompok kontrol. Hal ini bisa dikarenakan adanya faktor maturition atau kematangan dan retroactive history yang dapat mempengaruhi validitas internal dalam penelitian . Maturition adalah perubahan biologis dan atau perubahan psikologis yang sistematis pada organisme dalam satu waktu tertentu. Maturation salah satu faktor yang dapat mempengaruhi validitas internal dalam penelitian(Seniati, Yulianto dan Setiadi, 2011) . Faktor maturation lebih sering mempengaruhi validitas internal suatu penelitian yang menggunakan subyek anak-anak, karena perubahan biologis dan psikologis lebih cepat dibandingkan orang dewasa. Retroactive history hanya terjadi pada penelitian yang menggunakan pretest-postest, dikarenakan ada perubahan atau pengaruh yang dialami subyek diantara waktu pemberian pretest dan posttest yang tidak dapat dikontrol oleh peneliti (Seniati, Yulianto dan Setiadi, 2011).

\section{SIMPULAN}

Berdasarkan hasil penelitian dan pembahasan di atas, maka dapat disimpulkan bahwa metode bermain bermain peran " Aku Sayang Bumiku “ dapat miningkatkan sikap peduli lingkungan dan dapat digunakan sebagai salah satu metode untuk mengembangkan sikap peduli lingkungan pada anak pra sekolah khususnya TK. Berdasarkan hasil penelitian yang telah ditemukan, maka ada beberapa saran bagi guru yang dapat diberikan: a. Bermain peran bisa menjadi salah satu alternatif metode untuk mengajar dalam kelas, b. Guru yang memberikan metode bermain peran dituntut memiliki pengalaman berinteraksi dengan anak, dan sudah dikenal dekat oleh anak-anak sehingga dalam proses pelaksanaan bermain peran dapat berjalan dengan lancar dan tidak kaku. Saran bagi peneliti selanjutnya adalah Modul bemain peran "Aku Sayang Bumiku” perlu diperhatikan dalam segi manajemen waktu, sehingga semua anak yang terlibat dalam bermain peran memperoleh kesempatan untuk memerankan peran dalam setiap sesi. Modul bermain peran “ Aku Sayang Bumiku” perlu diujikan lagi kepada anak TK dari berbagai kelompok yang berbeda untuk melihat efektifitas modul.

\section{DAFTAR PUSTAKA}

Aisah, S. (2008). Perkembangan dan Konsep Dasar Pengembangan Anak Usia Dini. Jakarta: Universitas Terbuka

Alberta Water Council. (2007). Water Conservation, Efficiency and Productivity: Principles, Definitions, Performance Measures and Environmental Indicators.http:// albertawatercouncil.ca/Portals/0/ $\begin{array}{lccc}p & d & f & s\end{array}$

Azwar, S. (2011). Sikap Manusia (Teori dan Pengukurannya). Yogyakarta: Pustaka Pelajar.

Azwar, S. (2012). Penyusunan Skala Psikologi. Yogyakarta: Pustaka Pelajar.

Azwar, S. (2012). Validitas dan Reliabilitas. Yogyakarta: Pustaka Pelajar.

Barr, S. (2003). Strategies for Sustainability: Citizens and Responsble Environmental Behavior. Area 35.3. 227-240

Berkowitz, M. W,. Bier, M. C. (2004). Research- Based Character Education. Annals of the American Academy of Political and Social 
Science, volume. 591:72-85

Bjorklund, D.F. (2005). Children's Thinking (Cognitive Development and Individual Differences). Wadsworth, a Division of Thompson Learning Inc.

Bloomberg. M. R. (2007). Inventory of new York city, Greenhouse Gas Emmissions. New York City Mayor's Office of Long-Term Planning and Sustainability.

BPS. (2011). Laporan Bulanan Data Sosial Ekonomi. Jakarta

BPS. (2012). Indikator Perilaku Peduli Lingkungan Hidup (Hasil Survey Perilaku Peduli Lingkungan Hidup di 33 Ibu Kota Provinsi). BPS: Jakarta

Branch, J and Oberg, D. (2004). Focus on Inquiry: A Teacher's Guide to Implementing Inquiry-Based Learnin. Alberta Learning: Canada. http://www.learning.gov.ab.ca/k_12/ c u r riculu m/ b y S u b j e c t / focusoninquiry.pdf

Brederkamp. (1987). Developmentaly Appropriate Pratice In Early Childhood Program Serving Children from Birth to Age 8. Washington DC. NAEYC.

Bulach, C.R. (2002). Implementing a Character Education Curriculum and Assessing Its Impact on Student Behavior. The Clearing House, volume 76 (2), 7983.

Chu, H. E, dkk. (2007). Korean Year 3 Children's Enviromental Literacy: A prerequisite for a Korean environmental Education Curriculum. International Journal of Science
Education. Vol. 29, No. 6. Page 731746.

Davis, D. H. (2006). Character education in america's public schools. Journal of Church and State, 48 (1), 5-13.

Departemen Pendidikan Nasional. (2006). Pedoman Penerapan Pendekatan “ Beyond Centers And Circle Time (BCCT)” ( Pendekatan Sentra dan Lingkaran) Dalam Pendidikan Anak Usia Dini.

Dineen, J. (2007). Menghemat Energi. Grolier International Inc: Jakarta

Ehrampoush, M. H,. Halvani, G.H,. Barkhordari, A. dan Zare, M. (2012). Noise Pollution in Urban Environments: A Study in Yazd City, Iran. Journal of Environmental Study. Vol 21, No. 4 1095-1100.

Eick, C. J., \& Reed, C. J. (2002). What makes an inquiry-oriented science teacher? The influence of learning histories on student teacher role identity and practice. Science Education, 86(3), 401-416.

Febriani,A. (2010). Efektivitas Metode Bemain Peran untuk Meningkatkan Kecerdasan Moral Anak Usia Pra Sekolah. Tesis. Tidak diterbitkan. Yogyakarta: Universitas Gadjah Mada

Flanning, F. E (2011). Enganging Learners, Techniques to Make Training Stick. Profesional Safety. http:// www.asse.org.

Genevese, J. (2007). Global Warming (A Mind Mapper's Guide the Science and Solutions). http://www.live-thesolution.com 
Hoge. J.D.(2002). Character education, citizenship education, and the social studies. Social Studies, 93 (3), 103-108.

Hwang, Y.H, Kim, S.I and Jeng, J.M. (2000). Examining the Causal Ralationships Among Selected Antecedents of Responsible Enviromental Behavior. The Journal of Environmental Education, Vol. 31, No. 4 19-25.

Jaggi, B, Freedman, M, and Martin, C. (2011). Global Warming, Kyoto Protool, and the Need for Corporate Pollution Disclosures in India: A Case Study. International Journal of Bussiness, Humanities and Technology. Volume 1(3).

Jarvis, L, Odell, K and Troiano, M. (2002). Role-Playing as a Teaching Strategy.

IPCC .(2007). Climate Change 2007: The Physical Science Basis. Contribution of Working Group I to the Fourth Assessment Report of the Intergovernmental Panel on Climate Change. Cambridge University Press, Children and Participation (Reseach, monitoring, and evaluation with children and Young People)cc

Katilmis, A., Eksi, H., Oztrurk, C. (2011). Efficiency of Social Studies Integrated Character Education Program. Educational Sciences: Theory \& Practice, 11(2).

Kelin, D.A. (2007). The Perspective From Within: Drama and Children's Literature. Early Chillhood Education Journal, volume 35. 277284, doi: 10.1007/s10643-0070206-3.
Kementrian Pendidikan Nasional. (2011). Pedoman Pendidikan Karakter bagi AUD. Direktorat Jenderal Pendidikan Anak Usia Dini, Nonformal dan Informal. Direktorat Pendidikan AUD.

Kementerian Pendidikan Nasional. (2011). Panduan Pelaksanaan Pendidikan Karakter. Badan Penelitian dan Pengembangan Pusat Kurikulum dan Perbukuan.

Mageswary, K. Ismail, Z,. Norita, M. (2011). Green Chemistry: Educating Prospective Science Teachers in Education for Sustainable Development at School of Educational Studies, USM. Journal of Social Sciences No 7, Hal 42-50. ISSN 1549-3652

Meridith, S. (2011). Mengapa Aku Harus Peduli Pada Bumi?. Erlangga For Kids: Jakarta.

Moeslichatoen, R. (1999). Metode Pengajaran Di Taman Kanak-Kanak. Pusat Perbukuan Departemen Pendidikan dan Kebudayaan dan Rineka Cipta: Jakarta

Myers, D.G. (2008). Social Psychology. New York: McGraw-Hill Companies. Inc.

Oskamp, S. (2002). Enviromentally Responsible Behavior: Teaching and Promoting It Effenctively. Analyses of Social Issues and Public Policy, Vol. 2, No. 1, 173182

Paksu, A.D,. Ubuz, B. (2009) . Effects of DramaBased Geometry Instruction on Student Achievement, Attitudes, and Thinking Levels. The Journal of Educational Researh. Volume 102 (4). 
Parker, D.C, Nelson, J.S,. Burns, M.K. (2010). Comparison of Correlates of Classroom Behavior Problems in Schools With and Without a SchoolWide Character Education Program. Psychology in the Schools, volume 47 (8), doi: 10.1002/pits.20506.

Pui, S and Yeung, M. (2002). Teaching Approaches and the Development of Responsible Enviromental Behaviour: the Case of Hong Kong. Ethics, Place and Environment, Vol. 5, No.3, 239269, doi:10.1080/ 136687902200041579.

Polling, D.A., Hupp, J.M. (2009). Active Learning Through Role Playing, Virtual Babies In A Child Development Course. College Teaching, volume 57 (4).

Riechert, S.E., Leander, R.N., Lenhart, S.M. (2011).A Role-Playing Exercise That Demonstrates the Process of Evolution by Natural Selection: Caching Squirrels in a World of Pilferers. The American Biology Teacher, volume 73 (4) : 208212.doi: 10.1525/abt.2011.73.4.4.

Rivers, M. T. (2004). Ten essential for character education. The Journal of General Education, 53 (3/4), 247-260.

Seniati, L,. Yulianto, A., dan Setiadi, B.N. (2011). Psikologi Eksperimen. Indeks

Shadis, W. R., Cook, T.D,. Campbell, D.T. (2002). Experimental and Quasi experimental design for generalized causal inference. Boston: Houghton Mifflin Company.

Shaftel, F and Shaftel, G. (1982). Role Playing In The Curriculum. Prentice-Hall Inc: USA.
Strife, S. (2010). Reflecting on Environmental Education: Where Is Our Place in the Green Movement?. The Journal of Environmental Education, volume 41 (3),179-191. doi: 10.1080/ 00958960903295233.

Stott, P. A, Jones, G.A,. Mitchell, J.F. (2002). Do Models Underestimate the Solar Contribution to Recent Climate Change. Journal of Climate. volume 16.

Thiengkamol, N. (2011). Developmental of Model of Enviromental Education and Inspiration of Public Consciousness Influecing to Global Warming Alleviation. European Journal of Social Sciences, volume.25 (4): 506 514.

Topping, M.H. (1918). Nature Study in The Kindergarten. Parker School Year Book, volume 5:10-21

Veitch, S and Arkelin, D. (1995). Enviromental Psychology An Interdisciplinary Perspective. A Simon and Schuster Company. New Jersey

White, R and Warfa, N. (2011). Building Schools of Character: A Case-Study Investigation of Character Education's Impact on School Climate, Pupil Behavior, and Curriculum Delivery. Journal of Applied Psychology, volume 41 (1) : 45-60

Williams, H.R. (2010). Widening the Lens to Teach Character Education Alongside Standard Curriculum. The Clearing House, volume 83 :115-120, doi: 10.1080/00098651003653030.

Woolfolk, A.(2008). Educational Psychology. Pearson Education: Boston 


\section{4}

Wood, E., Cook, J. (2009). Gendered discourses and practices in role play activities: A Case Study of Young Children in the English Foundation Stage. Educational \& Child Psychology, volume 26 (2).

Wulan, R. (2011). Mengasah Kecerdasan Pada Anak. Pustaka Pelajar: Yogyakarta.

(2007). Dampak Perubahan Iklim Indonesia Masuk Kategori “Sangat Rentan”. Surya Pagi. 